\title{
HUBUNGAN PENGETAHUAN KEWIRAUSAHAAN DAN HASIL BELAJAR KONSTRUKSI KAYU DENGAN MINAT KEWIRAUSAHAAN SISWA KELAS XI PROGRAM KEAHLIAN TEKNIK KONSTRUKSI KAYU SMK NEGERI 1 LUBUK PAKAM
}

\author{
Lia Lusiana Ritonga ${ }^{1}$, Juanda Sianipar ${ }^{2}$ \\ ${ }^{1}$ Alumni Program Pendidikan Teknik Bangunan, Fakultas Teknik UNIMED \\ ${ }^{2}$ Dosen Pengajar Jurusan Pendidikan Teknik Bangunan, Fakultas Teknik UNIMED \\ (sianiparjuanda@gmail.com)
}

\begin{abstract}
ABSTRAK
Tujuan dari penelitian ini adalah untuk mengetahui hubungan pengetahuan kewirausahaan dan hasil belajar konstruksi kayu Siswa Kelas XI Program Keahlian Teknik Teknik Konstruksi Kayu SMK Negeri 1 Lubuk Pakam dengan jumlah responden 31 orang. Hasil analisis korelasi antar variabel didapat hasil : (1) variabel Pengetahuan Kewirausahaan $\left(X_{1}\right)$ dengan minat berwirausaha $(Y)$ yaitu $r_{\text {hitung }}=0,543>r_{\text {tabel }}=0,367$ menunjukkan korelasi positif dan berarti pada taraf signifikansi $5 \%$. (2) hasil belajar konstruksi kayu $\left(X_{2}\right)$ dengan minat berwirausaha $(y)$ yaitu $r_{\text {hitung }}=0,663>r_{\text {tabel }}=0,367$ menunjukkan korelasi positif dan berarti pada taraf signifikansi $5 \%$. Korelasi ganda antara $X_{1}$ dan $X_{2}$ terhadap $\mathrm{Y}$ menunjukkan korelasi yang positif dan berarti dengan $\mathrm{r}=0,74$ dan $\mathrm{R} 2=0,54$ yang berarti $54 \%$ pengetahuan kewirausahaan dan minat berwirausaha dapat ditingkatkan untuk meningkatkan minat berwirausaha dan sisanya dijelaskan dengan variabel lainnya.
\end{abstract}

Kata Kunci : Hasil Belajar, Minat Berwirausaha, Pengetahuan Kewirausahaan

\section{ABSTRACT}

The purpose of this research is to knows the relationship of knowledge Entrepreneurship Learning Outcomes and wood construction with an interest in Entrepreneurship Grade XI Wooden Construction Engineering Program SMK Negeri 1 Lubuk Pakam 31 respondents with a number of people. The results of the analysis of the correlation between variables obtained results: (1) Entrepreneurial Knowledge variables $\left(X_{1}\right)$ with an interest in entrepreneurship $(Y)$ rhitung $=0.543$ rtabel $=0.367>$ showed positive correlation and significance level at $5 \%$. (2) the results of the study of construction wood $\left(X_{2}\right)$ with an interest in entrepreneurship $(Y)$ rhitung $=0.663$ rtabel $=0.367>$ showed positive correlation and significance level at $5 \%$. Binary correlation between $X_{1}$ and $X_{2}$ against $Y$ shows a positive correlation and mean with $r=0.74$ and $R 2=0.54$ which means $54 \%$ entrepreneurial knowledge and interest in entrepreneurship can be improved to increase the interest in entrepreneurship and the rest is explained by other variables. 


\section{Pendahuluan}

Untuk menghasilkan Sumber Daya Manusia (SDM) yang berkualitas, pemerintah menetapkan tujuan dan fungsi pendidikan nasional. Undang-Undang Pendidikan Nasional (UUSPN) UU No. 20 (2003) tentang Sistem Pendidikan Nasional menyatakan bahwa fungsi dan tujuan yakni: pendidikan nasional berfungsi mengembangkan kemampuan dan membentuk watak serta peradaban bangsa yang bermartabat dalam rangka mencerdaskan kehidupan bangsa, bertujuan untuk mengembangkan potensi peserta didik agar menjadi manusia yang beriman dan bertaqwa kepada Tuhan Yang Maha Esa, berakhlak mulia, sehat, berilmu, cakap, mandiri, kreatif, dan menjadi warga negara yang demokratis serta bertanggung jawab.

Salah satu lembaga pendidikan yang menghasilkan SDM untuk mengembangkan potensi yaitu Sekolah Menengah Kejuruan (SMK). Hal ini menuntut SMK mengambil sikap tegas dalam menentukan identitas dirinya sebagai lembaga pendidikan atau penyedia sumber daya manusia yang mandiri dan kreatif. Hal ini sesuai dengan tujuan khusus yang ada dalam kurikulum SMK dengan KTSP 2006 menurut pusdiknas (2006) yang menyebutkan bahwa, SMK bertujuan untuk : 1). menyiapkan peserta didik agar menjadi manusia produktif, mampu bekerja mandiri, mengisi lowongan pekerjaan yang ada di dunia usaha dan dunia industri sebagai tenaga kerja tingkat menengah sesuai dengan kompetensi dalam program keahlian yang di pilihnya. 2). membekali peserta didik agar mampu memilih karier, ulet dan gigih dalam berkompetensi, beradaptasi di lingkungan kerja, dan mengembangkan sikap profesional dalam bidang keahlian yang di minatinya. 3). Membekali peserta didik dengan ilmu pengetahuan, teknologi, dan seni agar mampu mengembangkan diri dikemudian hari baik secara mandiri maupun melalui jenjang pendidikan yang lebih tinggi, dan 4). Membekali peserta didik dengan kompetensikompetensi yang sesuai dengan program keahlian yang dipilih.

Sesuai dengan tujuan di atas, lulusan SMK diharapkan mampu bekerja secara mandiri yang dapat memasuki dunia usaha dan dunia industri sesuai dengan kemampuan yang di milikinya. Dengan usia siswa yang rata-rata masih dalam masa produktif, maka SMK menjadi sangat penting dalam menyiapkan tamatan yang siap memasuki dan menciptakan lapangan kerja. Untuk menyiapkan peserta didik menjadi manusia yang produktif, mereka dibekali dengan mata pelajaran kewirausahaan.

Kewirausahaan merupakan suatu disiplin ilmu yang diajarkan dengan menerapkan prinsip-prinsip dan metodologi ke arah pembentukan kecakapan hidup (life skill) pada siswa melalui kurikulum yang terintegrasi yang dikembangkan di sekolah.

Kenyataannya, tingginya angka pengangguran di Indonesia semakin memprihatinkan. Menurut data Badan Pusat Statistik (BPS), jumlah pengangguran pada Febuari 2015 meningkat jika dibandingkan pada Agustus 2014 sebanyak yang meningkat sekitar 210 ribu orang. Sedangkan pada Februari 2015 meningkat 300 ribu orang. Data BPS menjabarkan bahwa tingkat pengangguran terbuka (TPT) didominasi yang berpendidikan Sekolah Menengah Kejuruan (SMK) sebesar 9,05 persen, disusul jenjang Sekolah Menengah Atas (SMA) 8,17 persen, dan Diploma I/II/III sebesar 7,49 persen. Selama setahun terakhir TPT yang mengalami peningkatan pengangguran yakni mereka yang pendidikan SMK 1,84 poin, Diploma I/II dan III sebesar 1,62 poin dan universitas 1,03 poin (BPS, 2015).

Dari hasil observasi yang diperoleh tentang minat berwirausaha yang dilakukan di SMK Negeri 1 Lubuk Pakam dapat dilihat pada Tabel di bawah ini.

Tabel 1 Hasil Observasi Minat Berwirausaha

\begin{tabular}{|c|c|c|c|}
\hline Rentangan & $\boldsymbol{f}_{\text {absolut }}$ & $\begin{array}{c}\boldsymbol{f}_{\text {relatif }} \\
(\%)\end{array}$ & Kategori \\
\hline $\begin{array}{c}98 \mathrm{~s} / \mathrm{d} \text { ke } \\
\text { atas }\end{array}$ & 2 & $8,4 \%$ & Tinggi \\
\hline $75 \mathrm{~s} / \mathrm{d} 97$ & 3 & $12,5 \%$ & Cukup \\
\hline $53 \mathrm{~s} / \mathrm{d} 74$ & 9 & $37,5 \%$ & Kurang \\
\hline $\begin{array}{c}52 \mathrm{~s} / \mathrm{d} \text { ke } \\
\text { bawah }\end{array}$ & 10 & $41,6 \%$ & Rendah \\
\hline \begin{tabular}{c} 
Jumlah \\
\hline
\end{tabular} & 24 & $100 \%$ & \\
\hline
\end{tabular}

Sumber: SMK N. 1 Lubuk Pakam 


\section{Hubungan Pengetahuan Kewirausahaan dan Hasil Belajar Konstruksi Kayu Dengan Minat Kewirausahaan Siswa Kelas XI Program Keahlian Teknik Konstruksi Kayu SMK Negeri 1 Lubuk Pakam}

Dari data Tabel menunjukkan bahwa siswa SMK Negeri 1 Lubuk Pakam mempunyai tingkat minat berwirausaha yang cenderung rendah di mana terdapat 10 dari 24 siswa dengan $f_{\text {relatif }} 41,60 \%$. Hal ini dipicu kebanyakan siswa beralasan bahwa tidak adanya modal untuk membangun usaha. Sebagian siswa juga belum tahu apa yang akan dilakukan setelah lulus, ada yang melanjut ke perguruan tinggi dan ada yang setelah tamat mencari kerja. Padahal jika siswa yakin dan mempunyai minat berwirausaha, bisa dikatakan dapat menyediakan lapangan kerja untuk dirinya.

Teknik Bangunan merupakan salah satu program studi keahlian di SMK Negeri 1 Lubuk Pakam yang akan mendidik peserta didiknya menjadi manusia yang mampu mengaplikasikan ilmunya di dunia industri. Selain itu, diajarkan ketrampilan sesuai dengan keahlian dibidangnya. Sehingga setelah mereka lulus diharapkan timbul keinginan untuk berwirausaha jika mereka tidak ingin melanjutkan ke perguruan tinggi.

Teknik konstruksi kayu adalah salah satu bidang keahlian teknik bangunan yang ada di SMK Negeri 1 Lubuk Pakam yang sangat potensial yang dibutuhkan di dunia kerja maupun dalam berwirausaha. Dengan mempelajari proses pembuatan konstruksi kayu, siswa lulusan SMK diharapkan menguasai segala sesuatu yang relevan di bidang teknik konstruksi kayu sehingga dapat dijadikan modal keterampilan dalam dunia kerja dan industri maupun dalam berwirausaha. Secara khusus tujuan program keahlian teknik konstruksi kayu adalah membekali peserta didik dengan pengetahuan, keterampilan dan sikap agar berkompeten.

Pengetahuan kewirausahaan dan hasil belajar konstruksi kayu siswa juga ikut mempengaruhi minatnya dalam berwirausaha. Pengetahuan, dan keterampilan yang dimiliki oleh siswa khususnya dalam teknik konstruksi kayu dapat mendorong tumbuhnya minat untuk berwirausaha. Minat tidak dibawa sejak lahir tetapi tumbuh dan berkembang sesuai dengan faktor-faktor yang mempengaruhinya. Dengan bekal pengetahuan serta keterampilan yang dimiliki siswa SMK diharapkan dapat menciptakan lapangan pekerjaan (job cretor). Ketika seorang siswa memiliki minat berwirausaha, maka akan termotivasi untuk belajar. Minat berwirausaha juga akan menjadi motivator bagi siswa untuk mencapai prestasi belajar yang lebih maksimal.

Oleh karena itu, minat berwirausaha diharapkan dapat memberikan dampak positif. Melalui bekal pengetahuan kewirausahaan dan hasil belajar konstruksi kayu berarti telah memiliki keterampilan dan keahlian yang baik di bidang teknik konstruksi kayu sehingga diharapkan mampu bersaing di dunia kerja dan mampu menciptakan lapangan kerja.

Berdasarkan latar belakang yang telah dipaparkan, maka penulis tertarik untuk melakukan penelitian tentang hubungan pengetahuan kewirausahaan dan hasil belajar konstruksi kayu dengan minat berwirausaha siswa kelas XI Program Keahlian Teknik Konstruksi Kayu SMK Negeri 1 Lubuk Pakam.

\section{Kajian Teori}

Minat berwirausaha adalah keinginan, ketertarikan serta kesediaan untuk bekerja keras atau berkemauan keras dengan adanya pemusatan perhatian untuk berusaha memenuhi kebutuhan hidupnya tanpa merasa takut akan resiko yang akan dihadapi, senantiasa belajar dari kegagalan yang dialami, serta mengembangkan usaha yang diciptakannya. Selain itu, minat berwirausaha meliputi sikap umum terhadap wirausaha, kesadaran spesifik untuk menyukai wirausaha, merasa senang dengan wirausaha, wirausaha mempunyai arti atau penting bagi individu, adanya minat intrinsik dalam wirausaha.

Menurut Notoatmodjo (2003:112), pengetahuan (knowledge) adalah hasil tahu dari manusia yang sekedar menjawab pertanyaan "What". Pengetahuan merupakan hasil dari tahu, dan ini terjadi setelah orang melakukan penginderaan terhadap suatu objek tertentu. Penginderaan, penciuman, rasa, dan raba. Pengatahuan atau kognitif merupakan domain yang sangat penting dalam membentuk tindakan seseorang (overt behavior).

Drucker (1985:3) mengartikan kewirausahaan sebagai semangat, kemampuan, sikap dan perilaku individu dalam menangani usaha (kegiatan) yang mengarah pada upaya mencari, menciptakan, menerapkan cara kerja, teknologi, dan produk baru dengan meningkatkan efisiensi dalam rangka 
memberikan pelayanan yang lebih baik dan atau memperoleh keuntungan yang lebih besar.

Dari beberapa pengertian di atas dapat dikatakan bahwa pengetahuan kewirausahaan adalah segala informasi atau berbagai gejala yang ditemui dan diketahui oleh manusia melalui panca indra dan akalnya tentang suatu usaha untuk membangun suatu value dengan kemampuan, keberanian, keteguhan hati dan kreatifitas serta berani mengambil resiko untuk peluang menuju sukses untuk membuka usaha dalam berbagai kesempatan dengan mengetahui apa saja faktor-faktor yang menjadi pangkal keberhasilan seseorang menuju kesuksesan tersebut.

Pandangan seseorang guru terhadap pengertian belajar akan mempengaruhi tindakannya dalam membimbing siswa untuk belajar. Berbicara pengertian belajar telah banyak konsep yang dirumuskan oleh para ahli yang berhubungan dengan teori belajar. Teori belajar behaviorisme (tingkah laku) menyatakan bahwa belajar adalah proses perubahan tingkah laku. Seseorang telah dianggap telah belajar sesuatu bila ia mampu menunjukkan tingkah laku. Selanjutnya, teori belajar kognitivisme menyatakan bahwa belajar adalah perubahan persepsi dan pemahaman (Uno, dkk, 2008).

Menurut Sudjana (2010:22), hasil belajar adalah kemampuan yang dimiliki siswa setelah menerima pengalaman belajar. Selanjutnya Warsito (dalam Depdiknas, 2006:125) mengemukakan bahwa hasil dari kegiatan belajar ditandai dengan adanya perubahan perilaku ke arah positif yang relatif permanen pada diri orang yang belajar. Menurut Munadi (Rusman, 2012) faktor-faktor yang mempengaruhi hasil belajar antara lain meliputi faktor internal dan faktor eksternal.

Teknik konstruksi kayu merupakan program keahlian yang terdapat di SMK Negeri 1 Lubuk Pakam dengan berbagai bidang studi keahlian. Salah satu bidang studi yang diteliti adalah konstruksi kayu tidak hanya berisi materi pelajaran seputar pengetahuan tentang kayu tetapi juga bentuk kegunaan kayu itu sendiri dalam bentuk praktek kerja konstruksi kayu terutama dalam jurusan teknik bangunan.

Hamalik (2010) menyatakan konstruksi kayu merupakan mata pelajaran yang diajarkan di SMK Program Keahlian Teknik Konstruksi Kayu. Mata pelajaran ini termasuk salah satu mata pelajaran kejuruan yang bertujuan pada penguasaan bagaimana memahami persiapan pelaksanaan merakit dan mengetahui tentang perakitan serta mengenal bagian-bagian komponen dari bahan kayu. Mata pelajaran Teknik Konstruksi Kayu dalam kompetensi membuat kusen, daun pintu, dan jendela kayu merupakan salah satu kompetensi yang harus dikuasai oleh siswa menengah kejuruan.

Dengan demikian dapat disimpulkan bahwa hasil belajar konstruksi kayu merupakan tingkat pencapaian yang diperoleh siswa berupa kemampuan kognitif, afektif, dan psikomotorik yang dinyatakan dengan nilai yang diperoleh dari serangkaian tes hasil belajar dalam materi kusen, daun pintu dan jendela.

\section{Metodologi Penelitian}

Penelitian ini dilakukan di SMK Negeri 1 Lubuk Pakam Jalan Galang, Kabupaten Deli Serdang untuk mengetahui hubungan pengetahuan kewirausahaan dan hasil belajar teknik konstruksi kayu dengan minat berwirausaha siswa kelas XI Program Keahlian Teknik Konstruksi Kayu SMK Negeri 1 Lubuk Pakam Pakam pada semester genap Tahun Ajaran 2015/2016.

Populasi keseluruhan siswa kelas XI Program Keahlian Teknik Konstruksi Kayu berjumlah 68 siswa. Teknik pengambilan sampel penelitian dilakukan dengan teknik random sampling secara sederhana yaitu dengan cara pengambilan sampel secara acak sehingga diperoleh sampel penelitian ini yaitu 31 orang.

Metode yang digunakan dalam penelitian ini adalah metode deskriptif kolerasional dengan pendekatan kuantitatif. Penelitian ini menggunakan tiga variabel, yaitu pengetahuan kewirausahaan $\left(\mathrm{X}_{1}\right)$ dan hasil belajar teknik konstruksi kayu $\left(\mathrm{X}_{2}\right)$, serta minat berwirausaha (Y).

Uji coba instrumen pada penelitian ini dilakukan pada kelas XII Teknik Konstruksi Kayu SMK Negeri 1 Lubuk Pakam dengan jumlah siswa 20 orang. Dari hasil uji coba instrumen tes pengetahuan kewirausahaan diketahui dari 30 butir item yang disusun ada 22 butir soal yang digunakan dan 8 item soal yang tidak digunakan. Selanjutnya Dari hasil uji coba instrumen tes hasil belajar Konstruksi Kayu diketahui dari 30 butir item yang disusun ada 5 item soal yang tidak digunakan dan 25 item soal digunakan.

Dari hasil uji coba instrumen angket Minat Berwirausaha diketahui dari 25 butir angket 


\section{Hubungan Pengetahuan Kewirausahaan dan Hasil Belajar Konstruksi Kayu Dengan Minat Kewirausahaan Siswa Kelas XI Program Keahlian Teknik Konstruksi Kayu SMK Negeri 1 Lubuk Pakam}

yang telah di uji coba terdapat 5 butir angket yang tidak digunakan dan 20 butir angket digunakan.

Teknik analisis data adalah kegiatan mengelompokkan data berdasarkan variabel dan jenis responden, mendeskripsikan data, mencari tingkat kecendrungan variabel penelitian dan menguji persyaratan analisis.

Agar data penelitian yang diperoleh dapat dipakai dengan menggunakan analisis statistik pada uji coba hipotesis penelitian yang menerapkan rumus korelasi product moment, maka terlebih dahulu memenuhi persyaratan analisis. Untuk persyaratan analisis data setiap variabel penelitian, maka dilakukan uji persyaratan yaitu uji normalitas, uji linearitas, dan mencari persamaan regresi ganda.

Untuk menguji hipotesis yakni : (1) hubungan antara pengetahuan kewirausahaan dengan minat berwirausaha (2) hubungan antara hasil belajar teknik konstruksi kayu dengan minat berwirausaha menggunakan perhitungan koefisien korelasi antar variabel bebas dengan variabel terikat digunakan rumus Product Moment seperti yang dikemukakan oleh Sudjana (2005) sebagai berikut :

$$
r_{x y}=\frac{\left(\mathrm{n} \cdot \sum \mathrm{XY}\right)-\left(\sum X\right)\left(\sum Y\right)}{\sqrt{\left.\left\{\left(n \sum X^{2}\right)-\left(\sum X\right)^{2}\right\} n \sum Y^{2}-\left(\sum Y\right)^{2}\right\}}}
$$

Selanjutnya hasil korelasi diuji keberartian dengan rumus uji $\mathrm{t}$ seperti yang dikemukakan oleh Sudjana (2005) sebagai berikut:

$$
t=\frac{\mathrm{r} \sqrt{\mathrm{n}-2}}{\sqrt{1-r^{2}}}
$$

Selanjutnya untuk mengetahui derajat hubungan antara suatu variabel bebas dengan satu variabel terikat digunakan rumus korelasi parsial dengan cara mengkondisikan variabel bebas lainnya dibuat tetap atau konstan dalam analisis multiple corelations digunakan rumus korelasi parsial.

Besar $t_{\text {hitung }}$ yang diperoleh dikonsultasikan terhadap $t_{\text {tabel }}$ pada tabel taraf signifikan $5 \%$ dengan $d k=N-1$. Bila $t_{\text {hitung }}$ $>t_{\text {tabel }}$, maka dapat disimpulkan bahwa hubungan mempunyai konstribusi yang positif dan berarti antara variabel bebas terhadap variabel terikat, dimana variabel bebas lain dikontrol.

\section{Hasil dan Pembahasan}

Dalam penelitian ini data yang diambil ada tiga jenis yaitu: Pengetahuan Kewirausahaan $\left(X_{1}\right)$ dengan menggunakan instrumen penelitian (tes objektif), Hasil Belajar Konstruksi Kayu $\left(X_{2}\right)$ dengan menggunakan instrumen penelitian (tes objektif), dan Minat Berwirausaha (Y) dengan menggunakan instrumen penelitian (angket). Berdasarkan pengolahan data akan diuraikan berurutan tentang deskripsi data, tingkat kecenderungan masing-masing variabel penelitian, pengujian persyaratan analisis, dan pengujian hipotesis.

Berdasarkan data variabel Pengetahuan Kewirausahaan $\left(X_{1}\right)$ yang diperoleh dengan jumlah responden 31 orang siswa, skor tertinggi 23; skor terendah 16; dengan mean (M) $=19,452$; dan standart deviation $(\mathrm{SD})=1,793$ dengan rentang $(\mathrm{R})=7$; banyak kelas $(\mathrm{BK})=5$; dan panjang kelas $(P)=2$. Dari hasil distribusi frekuensi data ubahan Pengetahuan Kewirausahaan $\left(\mathrm{X}_{1}\right)$ dapat digambarkan histogram distribusi skor berdasarkan kelas interval dan frekuensi absolut.

Untuk mengetahui tingkat kecenderungan setiap ubahan penelitian digunakan rata-rata ideal dan standart ideal yang dikategorikan yaitu: tinggi, cukup, kurang, dan rendah. Berdasarkan hasil perhitungan Pengetahuan Kewirausahaan, hasil Belajar Konstruksi Kayu siswa kelas XI Program Keahlian Teknik Konstruksi Kayu SMK Negeri 1 Lubuk Pakam dan Minat Berwirausaha siswa kelas XI Program Keahlian Konstruksi Kayu SMK Negeri 1 Lubuk Pakam termasuk Kategori Tinggi.

Tujuan dilakukan uji normalitas adalah untuk mengetahui normal atau tidak normalnya data penelitian tiap variabel penelitian. Pengujian ini dilakukan dengan menggunakan uji liliefors. Syarat normal dipenuhi apabila $\mathrm{L}_{\text {hitung }}<\mathrm{L}_{\text {tabel }}$. Normal atau tidak normalnya data ditentukan dengan mengkonsultasikan harga Lhitung yang diperoleh dengan taraf $\mathrm{L}_{\text {tabel }}$ dengan taraf signifikansi $5 \%$. Berikut ini disajikan hasil analisis dari variabel penelitian. 


\begin{tabular}{|c|c|c|c|c|}
\hline No & $\begin{array}{c}\text { Variabel } \\
\text { Penelitiaan }\end{array}$ & L $_{\text {hitung }}$ & Ltabel & $\begin{array}{c}\text { Kesimpul } \\
\text { an }\end{array}$ \\
\hline 1 & $\mathrm{Y}$ atas $\mathrm{X}_{1}$ & 0,156 & 0,159 & Normal \\
\hline 2 & $\mathrm{Y}_{1}$ atas $\mathrm{X}_{2}$ & 0,157 & 0,159 & Normal \\
\hline
\end{tabular}

Dari perhitungan Korelasi Product Moment diperoleh koefisien korelasi antara $X_{1}$ dengan $Y$ $=0,543$ sedangkan $r_{\text {tabel }}$ dengan $\mathrm{N}=31-2=29$ dan taraf signifikansi 5\% sebesar 0,367. Dengan demikian harga $r_{X 1 Y}>r_{\text {tabel }}(0,543>0,367)$. Selanjutnya dilakukan uji keberartian korelasi dengan menggunakan Uji-t diperoleh $t_{\text {hitung }}$ 3,486 . Harga tabel untuk $N=31-2=29$ pada taraf signifikansi $5 \%$ adalah 1,699 . Oleh karena $t_{\text {hitung }}>t_{\text {tabel }}(3,486>1,699)$ maka dapat dikatakan bahwa terdapat hubungan signifikan dan berarti antara Pengetahuan Kewirausahaan $\left(\mathrm{X}_{1}\right)$ dengan Minat Berwirausaha $(\mathrm{Y})$.

Selanjutnya untuk melihat hubungan murni tanpa variabel bebas lainnya, dilakukan Uji Korelasi Parsial diperoleh koefisien korelasi parsial antara $X_{1}$ dengan $Y=0,429$ sedangkan $\mathrm{r}_{\text {tabel }}$ dengan $\mathrm{N}=31-2=29$ dan taraf signifikansi $5 \%$ adalah 0,367 . Selanjutnya dilakukan uji keberartian korelasi parsial dengan menggunakan Uji-t diperoleh $t_{\text {hitung }}=$ 2,560 . Harga tabel untuk $N=31-2=29$ pada taraf signifikansi $5 \%$ adalah 1,699 . Oleh karena $t_{\text {hitung }}>t_{\text {tabel }}(2,560>1,699)$ maka dapat dikatakan terdapat hubungan signifikan dan berarti antara Pengetahuan Kewirausahaan dengan Minat Berwirausaha, dengan Hasil Belajar Konstruksi Kayu dikontrol.

Dari hasil perhitungan di atas, dapat disimpulkan hipotesis penelitian yang diajukan bahwa terdapat hubungan yang signifikan dan berarti antara Pengetahuan Kewirausahaan dengan Minat Berwirausaha serta teruji kebenarannya.

Dalam penelitian ini ditemukan bahwa terdapat hubungan yang signifikan dan berarti antara Pengetahuan Kewirausahaan dengan Minat Berwirausaha siswa kelas XI Program Keahlian Teknik Konstruksi Kayu SMK Negeri 1 Lubuk Pakam. Temuan ini menunjukkan bahwa Pengetahuan Kewirausahaan merupakan salah satu faktor pendukung minat berwirausaha siswa.

Dalam penelitian ini juga ditemukan bahwa terdapat hubungan yang signifikan dan berarti antara Hasil Belajar Konstruksi Kayu dengan Minat Berwirausaha siswa kelas XI Program Keahlian Teknik Konstruksi Kayu SMK Negeri 1 Lubuk Pakam. Temuan ini menunjukan bahwa Hasil Belajar Konstruksi Kayu merupakan salah satu faktor pendukung minat berwirausaha.

Selanjutnya dalam penelitian ini juga ditemukan bahwa terdapat hubungan yang signifikan dan berarti antara Pengetahuan Kewirausahaan dan Hasil Belajar Konstruksi Kayu secara bersama-sama dengan Minat Berwirausaha siswa kelas XI Program Keahlian Teknik Konstruksi Kayu SMK Negeri 1 Lubuk Pakam. Temuan ini menunjukan bahwa Pengetahuan Kewirausahaan dan Hasil Belajar Konstruksi Kayu merupakan faktor pendukung minat berwirausaha.

Dari semua penelitian di atas, variabel pengetahuan kewirausahaan dan hasil belajar konstuksi kayu sangat berperan untuk meningkatkan minat berwirausaha secara bersama-sama. Siswa yang memiliki minat untuk berwirausaha harus didukung oleh kepedulian berbagai pihak yang memiliki kepedulian untuk menanamkan jiwa kewirausahaan siswa. Dengan demikian dari lingkungan dan berbagai pihak yang baik dapat memberikan pendorong yang signifikan terhadap tumbuhnya wirausaha muda dari kalangan siswa terkhususnya Sekolah Menengah Kejuruan.

\section{Kesimpulan dan Saran \\ 5.1 Kesimpulan}

Berdasarkan hasil penelitian yang telah diuraikan dalam penelitian ini, maka dapat diambil kesimpulan sebagai berikut:

a. Terdapat hubungan yang signifikan dan berarti antara Pengetahuan Kewirausahaan dengan Minat Berwirausaha siswa kelas XI Program Keahlian Teknik Konstruksi Kayu SMK Negeri 1 Lubuk Pakam.

b. Terdapat hubungan yang signifikan dan berarti antara Hasil Belajar Konstruksi Kayu dengan Minat Berwirausaha siswa kelas XI Program Keahlian Teknik Konstruksi Kayu SMK Negeri 1 Lubuk Pakam.

c. Terdapat hubungan yang signifikan dan berarti secara bersama-sama antara Pengetahuan Kewirausahaan dan Hasil Belajar Konstruksi Kayu dengan Minat Berwirausaha siswa kelas XI Program Keahlian Teknik Konstruksi kayu SMK Negeri 1 Lubuk Pakam. 


\section{Hubungan Pengetahuan Kewirausahaan dan Hasil Belajar Konstruksi Kayu Dengan Minat Kewirausahaan Siswa Kelas XI Program Keahlian Teknik Konstruksi Kayu SMK Negeri 1 Lubuk Pakam}

\subsection{Saran}

Berdasarkan pembahasan, hasil penelitian dan kesimpulan penelitian di atas, maka dapat diajukan beberapa saran antara lain:

a. Mengingat besarnya hubungan Pengetahuan Kewirausahaan dan Hasil Belajar Konstruksi Kayu dengan Minat Berwirausaha, hendaknya siswa dapat mempertahankan dan meningkatkan lagi wawasan serta keinginan berwirausaha sebagai bekal untuk dirinya sendiri di masa mendatang.

b. Dengan ditemukannya Minat Berwirausaha pada siswa yang cenderung tinggi, perlu kiranya pihak sekolah/guru mempertahankan serta dilakukan peningkatan melalui dorongan ataupun memberikan pengalaman yang menarik tentang wirausaha seperti kunjungan langsung maupun pengamatan langsung terhadap proses produksi pada perusahaan seorang wirausaha.

c. Mengingat besarnya Minat Berwirausaha siswa diharapkan orang tua siswa dan lingkungan sekitar untuk mendorong dan memotivasi para siswa untuk menciptakan lapangan pekerjaan sendiri mengingat keterbatasan lapangan kerja saat ini.

d. Mengingat keterbatasan penelitian ini, maka disarankan bagi peneliti lainnya untuk mengadakan penelitian lebih lanjut. Guna menemukan faktor-faktor lain yang lebih dominan memberikan konstribusi terhadap Pengetahuan Kewirausahaan dan Hasil Belajar Konstruksi Kayu untuk meningkatkan Minat Berwirausaha.

e. Penelitian ini hanya meneliti pada faktorfaktor tertentu saja, untuk itu diharapkan kelak bagi para peneliti bisa meneliti faktor-faktor lainnya yang mempengaruhi minat berwirausaha yang tidak dibahas pada penelitan ini.

\section{Daftar Pustaka}

Arif, Muhammad. 2014. "Pengaruh pengetahuan kewirausahaan, self efficacy, dan karakter wirausaha terhadap minat berwirausaha pada siswa kelas XI SMK Negeri 1 Depok Kabupaten Sleman". Skripsi. UNY.
Ating, Tedjasutisna. 2004. Memahami kewirausahaan SMK Tingkat I. Bandung: Armico.

Badan Pusat Statistik. 2015. Lulusan SMK Dominasi Pengangguran. www.bps.go.id Diakses pada tanggal 29 September 2015.

Buchari, Alma. 2011. Kewirausahaan. Bandung: Alfabeta.

Cronbach, L.J. 1960. Essential of Psychological Testing. Asian Edition. Tokyo: Harper \& Brothers.

Dimyati, Mudjiono. 2009. Belajar dan Pembelajaran. Jakarta: Rineka Cipta.

Gronlund, Norman E. 1998. Assesment of Student Achievement. Sixth Edition. Boston: Allyn and Bacon.

Hamalik, Oemar. 2006. Proses Belajar Mengajar. Jakarta: PT Bumi Aksara

Mardiyatmo. 2008. Kewirausahaan untuk Kelas X. Surakarta: Yudistira.

Martin, Handoko. 2003. Motivasi Penggerak Tingkah Laku. Yogyakarta: Kanisius.

Norman, C. 2009. Konsep Kewirausahaan. Online. http://ciptonorman.com. Diakses pada tanggal 30 September 2015.

Riant, Nugroho, 2003. Memahani Latar Belakang Pemikiran Entrepreneurship Ciputra. Jakarta. PT. Alex Media Komputindo.

Republik Indonesia, 2003 Undang-Undang Sistem Pendidikan Nasional. Jakarta: Sekretariat Negara.

Sudjana. 2005. Statistika Pendidikan. Bandung: Tarsito.

Suharsimi Arikunto. 2010. Prosedur Penelitian Suatu Pendekatan Praktik. Jakarta: Rineka Cipta.

Uno, Hamzah B., Abdul Karim Rauf, dan Najamuddin Petta Solong. 2008. Pengantar Teori Belajar dan Pembelajaran. (Cet. II). Gorontalo: Nurul Jannah.

www.pusdiknakes.or.id/data/kurikulum/smk .doc. Diakses pada tanggal 8 September 2015. 